\title{
Ultrasound guided continuous paravertebral block in a patient with coronary heart disease and sleep apnea syndrome
}

\author{
Koroner arter hastalığı ve uyku apne sendromu olan bir hastada \\ ultrason eşliğinde sürekli paravertebral blok
}

Bilgiser ESEN,' Hüseyin Yüce BIRCAN,, Özlem ÇINAR, ' Ayda TÜRKÖZ'

\begin{abstract}
Summary
The case of a 77-year-old patient with severe coronary heart disease who underwent radical mastectomy with axillary lymph node dissection by ultrasound-guided continuous paravertebral block (CPVB) is described in the present report. Radical mastectomy with axillary dissection is a surgical procedure that necessitates endotracheal intubation and is usually performed under general anesthesia, which carries heightened risk for patients with coronary heart disease (CHD) and sleep apnea syndrome (SAS). Ultrasound-guided CPVB is a simple and safe alternative technique that allows for the use of anesthesia and postoperative analgesia with minimal side effects.
\end{abstract}

Keywords: Coronary heart disease; mastectomy; ultrasound-guided continuous paravertebral block.

\begin{abstract}
Özet
Bu olguda, 77 yaşında ciddi koroner arter hastalığı öyküsü olan, ultrason eşliğinde sürekli paravertebral blok tekniğiyle radikal mastektomi ve aksiller lenf nodu diseksiyonu uygulanan bir hasta sunuldu. Genellikle aksiller diseksiyon ve radikal mastektomi genel anestezi altında uygulanan bir cerrahi prosedür olup endotrakeal entübasyon gerektirir. Koroner arter hastalığı ve uyku apne sendromu olan hastalarda genel anestezi yüksek risklidir. Ultrason eşliğinde sürekli paravertebral blok tekniği basit ve güvenli bir anestezi alternatifi olduğu kadar minimal yan etkiyle ameliyat sonrası analjezi de sağlamaktadır.

Anahtar Kelimeler: Koroner arter hastalığı; mastektomi; ultrason eşliğinde sürekli paravertebral blok.
\end{abstract}

\section{Introduction}

We report here the use of ultrasound-guided continuous paravertebral block (CPVB) as a primary anesthetic technique in a patient with severe CHD and SAS undergoing radical mastectomy with axillary lymph node dissection for infiltrating ductal carcinoma.

Thoracic paravertebral block (TPVB) results in an ipsilateral somatic motor and sensory nerve block of multiple contiguous thoracic dermatomes above and below the site of injection. ${ }^{[1,2]}$ Location of the paravertebral space may be technically difficult, as location of the transverse process by blind needle placement is necessary and its overall failure rate is more than
$10 \%{ }^{[3]}$ Failure to identify the transverse process, results in several needle redirections which not only cause pain and discomfort but also increase the potential risk of pneumothorax. The use of ultrasound offers the capability to place a catheter in the paravertebral space with real-time image guidance. Sonographic measurements obtained using ultrasound scanning of vertebral transverse processes and parietal pleura can give an accurate measurement of the depth from the skin to the paravertebral space. ${ }^{[4]}$

Radical mastectomy with axillary dissection is a surgical procedure that is usually performed under general anesthesia and necessitates endotracheal intubation.

\footnotetext{
'Department of Anesthesiology and Reanimation, Baskent University Faculty of Medicine, Istanbul, Turkey ${ }^{2}$ Department of General Surgery, Baskent University Faculty of Medicine, Istanbul, Turkey

Submitted: 26.08.2013 Accepted after revision: 01.09.2014

Correspondence: Dr. Özlem Çınar. Başkent Üniversitesi Tıp Fakültesi, Anesteziyoloji ve Reanimasyon Anabilim Dalı, Istanbul, Turkey. Tel: +90 - 216-554 1500 e-mail: drozlem79@gmail.com

(c) 2016 Turkish Society of Algology
} 
Here we report a patient affected by coronary heart disease and sleep apne syndrome presenting with respiratory distress scheduled for radical mastectomy, in whom anesthesia was managed succesfully using only sedation with thoracic paravertebral block.

\section{Case Report}

A 77 years old, $69 \mathrm{~kg}, 155 \mathrm{~cm}$ woman, with American Society of Anesthesiology (ASA) physical status III was scheduled for right radical mastectomy with axillary lymph node dissection for infiltrating ductal carcinoma. She was suffering from severe CHD and SAS. She had left ventricular aneurysm and her left ventricular ejection fraction (LVEF) was $\% 25$. Since the patient presented a higher risk of complications for endotracheal intubation, we have decided to perform the procedure with CPVB. After discussing with the patient and her family, written informed consent was obtained.

One hour before surgery, midazolam $5 \mathrm{mg}$ was administered orally as premedication. Routine monitoring (pulse oximeter, noninvasive blood pressure cuff, and electrocardiogram) were applied, and intravenous access was established. Patient was intravenously administered $50 \mu \mathrm{gr}$ fentanyl as needed for block procedural sedation/analgesia. The initial blood pressure, heart rate and peripheral oxygen saturation were $160 / 80 \mathrm{mmHg}, 80$ beats/min and $94 \%$, respectively. Paravertebral injection was performed with the patient in the sitting position. Sonosite Ti$\tan$ (SonoSite, Bothell, Washington, USA) 7-13 MHz linear transducer was applied longitudinally to the paravertebral area.

The skin and subcutaneous tissue were anesthetized with $5 \mathrm{ml}$ lidocaine $(10 \mathrm{mg} / \mathrm{ml})$. An $18 \mathrm{G}$ Tuohy needle was inserted perpendicularly at T7 to hit the transverse process via an out-of-plane approach (Figure 1). The needle was then directed over the top of the bony structure. The deviation of the needle from the perpendicular line was kept at $15^{\circ}$. The paravertebral space was identified using loss of resistance to normal saline injection without ultrasound. After negative aspiration, test dose with $3 \mathrm{ml}$ 1\% lidocaine with epinephrine 1:200.000 was administered incrementally with ultrasound guidance. Catheter placement was performed by an attending anesthesiologist experienced in regional anesthetic techniques. 18 gauge, $10 \mathrm{~cm}$ Tuohy needle access followed by
20 gauge open tip, single orifice epidural catheter advanced $5 \mathrm{~cm}$ into the paravertebral space (Figure 2). During catheter placement, a surgical block was instituted with $0.3 \mathrm{ml} / \mathrm{kg}, 0.5 \%$ levobupivacaine. Onset of sensory loss occured 12 minutes after injection with surgical anesthesia ensuing 25 minutes after injection. Prior to incision, blood presure decreased to $110 / 55 \mathrm{mmHg}$. Intraoperative sedation was provided with IV $1 \mathrm{mg} /$ hours infusion of midazolam. Anesthesia depth was monitored with Index of Consciousness (IOC) (Morpheus Medical, Barcelona, Spain) during the operation, and $\mathrm{IOC}$ values were within 60-70.

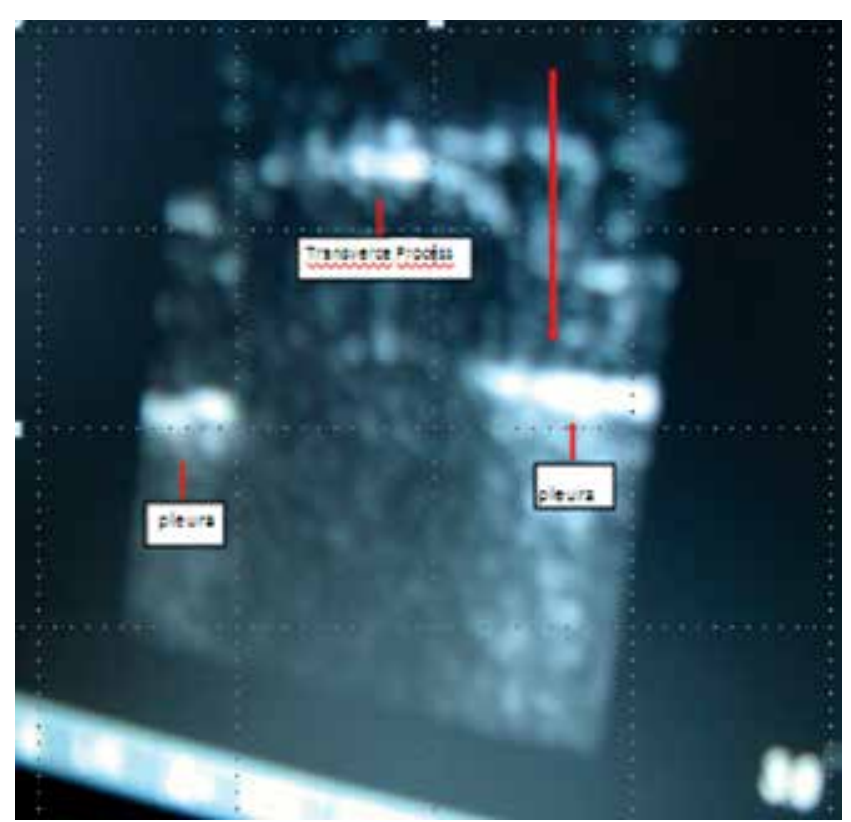

Figure 1. Ultrasound-guided paravertebral block in an 'out-ofplane' technique.

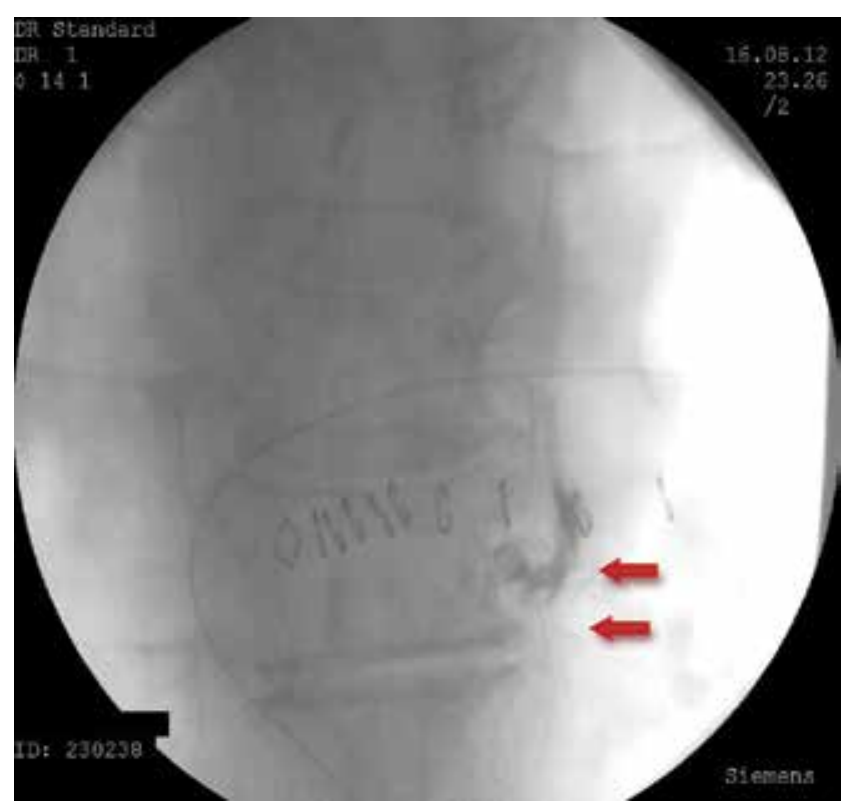

Figure 2. Distribution of the radioopaque that is given through the paravertebral catheter. 
Surgery lasted 135 minutes and the patient remained comfortable during the procedure (Figure 3 ).

Radical mastectomy was completed without any complication and the patient was transferred to the post anesthesia care unit (PACU). In the PACU, 5-10 $\mathrm{ml} / \mathrm{h}$ 0.25\% levobupivacaine infusion begun through the paravertebral catheter and continued for 48 hours. Pain scores; at rest, on movement and during coughing were evaluated for $48 \mathrm{hrs}$ in the postoperative period using a numeric rating scale (NRS) ranging from 0 (no pain) to 10 (worst imaginable pain) (Figure 4). Nausea and vomiting were seen neither in PACU nor in ward. During her hospitalization, there was no need for opioid medication and the patient was discharged on the third postoperative day.

\section{Discussion}

The main finding of this case report was that adequate intraoperative anesthesia and postoperative analgesia can be achieved by ultrasound guided CPVB, in a patient with CHD and SAS, undergoing radical mastectomy.

Regional anesthesia using paravertebral block is an alternative to general anesthesia for breast cancer surgery. ${ }^{[5]}$ The technique provided good operative anesthesia for major chest wall procedures as well as good postoperative analgesia. ${ }^{[6]}$ Benefits include, reduction in postoperative nausea and vomiting and potential for ambulatory discharge. Infiltration of the paravertebral space results in unilateral sensory, motor and sympathetic blockade. So, this technique could facilitate maintenance of the normal haemodynamic status. ${ }^{[7]}$ PVB can provide profound, long-lasting sensory differentiation. As a result, greater attenuation of the surgical stress response may be transformed into reduced inotropic stimulation of the heart.

Additionally, unlike general anesthesia, PVB ensures superior postoperative analgesia, shortens recovery and hospitalization time, decreases analgesic requirement. Also, the use of PVB in patients undergoing ambulatory breast cancer surgery has a costsaving potential. ${ }^{[1]}$

This case demonstrates that, older patients with multiple comorbidities can undergo radical mastectomy using CPVB with the avoidance of general an-

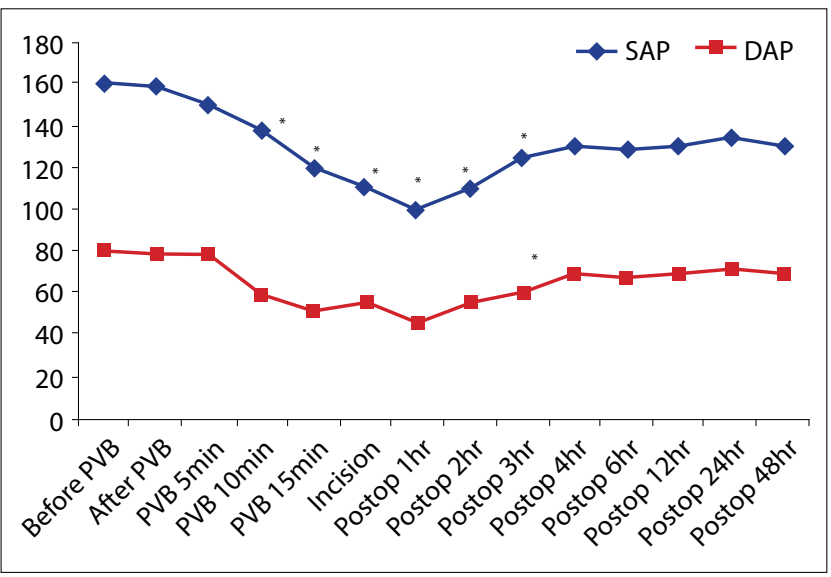

Figure 3. Systolic and diastolic blood pressure values. ${ }^{*} \mathrm{P}<0.05$ in the groups.

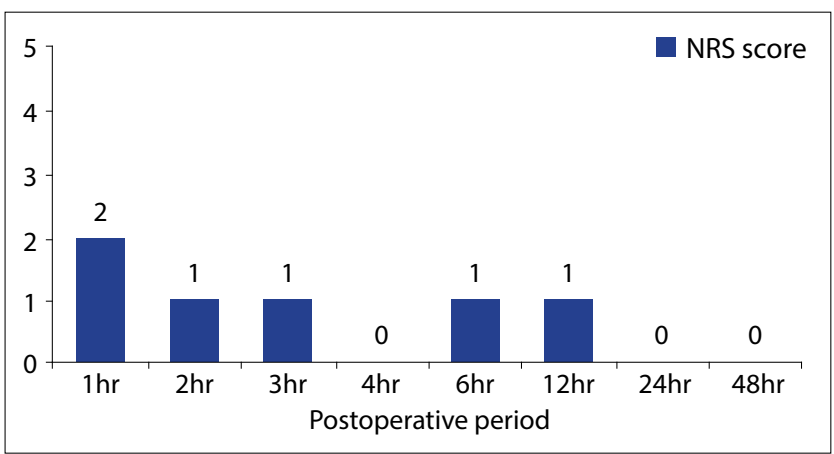

Figure 4. Postoperative pain scores.

esthesia. First of all, opioids were not used and blood pressure and heart rate were stable during the operation. Secondly, pain scores at rest, on movement and during coughing did not increase above 1 during the postoperative 48 hours. That's why, this technique should be considered as a potential anesthetic management in such patients.

The use of paravertebral catheters in the management of thoracic pain after surgery or trauma has been well described. ${ }^{[8,9]}$ Percutaneous paravertebral catheters have traditionally been placed using the method described by Eason and Wyatt ${ }^{[3]}$ using loss of resistance to air or saline with needle and syringe. Although accidental pleural puncture is rare, ${ }^{[10]}$ paravertebral block is still considered potentially dangerous by many anesthetist. ${ }^{[5]}$ Using ultrasound to visualize anatomical landmarks, it will be possible to improve the safety of the block. Ultrasound imaging not only helps to determine needle insertion sites, but also provides information about the depth to the paravertebral space. ${ }^{[1]} \mathrm{UI}-$ trasound guided CPVB is a simple and safe alternative technique that offers anesthesia as well as postoperative analgesia with minimal side-effects. 
Conflict-of-interest issues regarding the authorship or article: None declared.

\section{Peer-rewiew: Externally peer-reviewed.}

\section{References}

1. Karmakar MK. Thoracic paravertebral block. Anesthesiology 2001;95(3):771-80.

2. O Riain SC, Donnell BO, Cuffe T, Harmon DC, Fraher JP, Shorten $\mathrm{G}$. Thoracic paravertebral block using real-time ultrasound guidance. Anesth Analg 2010;110(1):248-51.

3. Eason MJ, Wyatt R. Paravertebral thoracic block-a reappraisal. Anaesthesia 1979;34(7):638-42.

4. Pusch F, Wildling E, Klimscha W, Weinstabl C. Sonographic measurement of needle insertion depth in paravertebral blocks in women. Br J Anaesth 2000;85(6):841-3.

5. Richardson J, Sabanathan S. Thoracic paravertebral analgesia. Acta Anaesthesiol Scand 1995;39(8):1005-15.
6. Buckenmaier CC 3rd, Klein SM, Nielsen KC, Steele SM. Continuous paravertebral catheter and outpatient infusion for breast surgery. Anesth Analg 2003;97(3):715-7.

7. Karmakar MK. Thoracic paravertebral block. Anesthesiology 2001;95(3):771-80.

8. Dhole S, Mehta Y, Saxena H, Juneja R, Trehan N. Comparison of continuous thoracic epidural and paravertebral blocks for postoperative analgesia after minimally invasive direct coronary artery bypass surgery. J Cardiothorac Vasc Anesth 2001;15(3):288-92.

9. Paniagua $P$, Català E, Villar Landeira JM. Successful management of pleuritic pain with thoracic paravertebral block. Reg Anesth Pain Med 2000;25(6):651-3.

10. Lönnqvist PA, MacKenzie J, Soni AK, Conacher ID. Paravertebral blockade. Failure rate and complications. Anaesthesia 1995;50(9):813-5.

11. Hara K, Sakura S, Nomura T, Saito Y. Ultrasound guided thoracic paravertebral block in breast surgery. Anaesthesia 2009;64(2):223-5. 